ISSN (Print) : :1412-7601

ISSN (Online) : 2654-8712

Volume 5, No.2 September 2019

EKONOBIS

http://www.ekonobis.unram.ac.id

\title{
Analisis Efisiensi Dan Nilai Tambah Usaha Agroindustri Pengolahan Dodol Nangka (Studi Kasus Industri Rumah Tangga di Kecamatan Narmada)
}

\section{Suprianto, I Gusti Ayu Eka Damayanti}

Universitas Mataram

\begin{tabular}{l}
\hline ARTICLE INFO \\
Keywords : \\
Efficiency Analysis, Value \\
Added, Processing \\
jackfruit dodol, narmada \\
district
\end{tabular}

Kata Kunci :

Analisis Efisiensi,Nilai

Tambah, Pengolahan

dodol nangka,kecamatan

narmada
ABSTRACT : This study aims to analyze the costs incurred per one time production process in the jackfruit dodol processing industry business, the level of efficiency and added value created from processing jackfruit fruit into jackfruit dodol. Research Locations in Narmada Subdistrict, West Lombok Regency by sampling respondents of 6 respondents determined by accident or accidental sampling. Methods of data collection using primary data conducted using questionnaires through interviews include data on the components of production costs, type of equipment and input prices. The analysis shows that the average cost of one-time production of jackfruit dodol processing from the six respondents ranged from $R p$ 209,874, the lowest and highest of $R p$ 490,541.64 with an average income reaching between $R p 357,513.67$ to $R p 807,583$. The efficiency level of the six respondents shows $>1$, which means that jackfruit dodol business is feasible (the lowest efficiency rate is 2.46 , the highest is 3.17 ). While the added value created from the processing of jackfruit fruit into jackfruit jackfruit means that the six respondents showed that the average added value of processed jackfruit dodol agro-industry was Rp. 82,520, meaning that for every $1 \mathrm{~kg}$ of jackfruit fruit processed into jackfruit dodol, it could provide an additional value of 82.520 , this shows that processed jackfruit dodol products have good prospects when viewed from the added value generated.

ABSTRAK: Penelitian ini bertujuan untuk menganalisis biaya-biaya yang dikeluarkan per satu kali proses produksi dalam usaha industri pengolahan dodol nangka, tingkat efisiensi serta Nilai Tambah yang diciptakan dari pengolahan buah nangka menjadi dodol nangka. Lokasi Penelitian di Kecamatan Narmada Kabupaten Lombok Barat dengan pengambilan sampel responden sebanyak 6 responden ditentukan dengan tanpa sengaja atau cara accidental sampling. Metode pengumpulan data dengan menggunakan data primer yang dilakukan dengan menggunakan kuesioner melalui wawancara meliputi data komponen biaya produksi, jenis peralatan dan harga input. Hasil analisis menunjukkan bahwa besarnya biaya rata-rata sekali produksi pengolahan dodol nangka dari ke enam responden adalah berkisar antara Rp 209.874, yang terendah dan tertinggi sebesar $R p$ 490.541,64 dengan rata-rata perolehan pendapatan mencapai antara $R p$ 357.513,67 sampai dengan Rp 807.583 . Tingkat efisiensi dari ke enam responden menunjukkan $>1$, yang berarti usaha dodol nangka layak untuk diusahakan ( angka efisiensi terendah 2,46 tertinggi 3,17). Sedangkan nilai tambah yang diciptakan dari pengolahan buah nangka menjadi dodol nangka dariartinya bahwa ke enam responden menunjukkan bahwa Rata-rata Nilai Tambah agroindustri olahan dodol nangka sebesar Rp 82.520, artinya bahwa untuk setiap $1 \mathrm{Kg}$ buah nangka yang diolah menjadi dodol nangka dapat memberikan penambahan nilai sebesar 82.520, ini menunjukkanbahwa produk olahan dodol nangka memiliki prospek yang baik jika dilihat dari nilai tambah yang dihasilkan.

Corresponding Author :

Alamat : Program Studi Ekonomi Pembangunan, Fakultas Ekonomi dan Bisnis, Universitas Mataram, Jln. Majapahit No. 62 Mataram.

e-mail: suprianto@unram.ac.id 


\section{PENDAHULUAN}

\section{Latar Belakang}

Sektor industri memiliki peranan yang penting di dalam pembangunan yaitu dalam rangka menciptakan pertumbuhan ekonomi baik sekala nasional maupun skala regional. Sektor industri ini keberadaannya tidak terlepas dari sektor pertanian yang merupakan sektor basis di Indonesia dalam menopang perekonomian secara agregat. Keberadaan sektor industri baik industri hulu maupun hilir mempunyai kontribusi yang besar untuk mengurangi ketergantungan impor baik terhadap kebutuhan bahan dalam negeri maupun barang-barang modal seperti mesin-mesin pengolah produ-produk yang dihasilkan oleh sektor pertanian. Salah satu dari sektor industri yang keberadaannya sangat strategis adalah industri pangan yang mengolah hasil pertanian baik dari produk nabati maupun hewani menjadi produk olahan untuk memenuhi kebutuhan pangan masyarakat indonesia. Industri pangan ini kedepan memiliki prospek yang baik karena produkproduknya selalu dibutuhkan oleh manusia setiap saat untuk memenuhi kebutuhan pangan rumah tangga maupun dunia usaha yang merupakan kebutuhan dasar untuk kelangsungan hidup manusia.

Pengembangan usaha agribisnis dibidang pertanian terus digalakkan oleh pemerintah dengan mengembangkan kegiatan bisnis pertanian atau yang lebih dikenal dengan usaha agribisnis. Usaha agribisnis adalah kegiatan yang berhubungan dengan penanganan komoditi pertanian atau usaha dibidang pertanian yang mecakup seluruh produkproduk yang dihasilkan oleh sektor pertanian termasuk di dalamnya peternakan dalam bentuk bahan baku mentah. Bahan mentah dari produk pertanian ini untuk menjadi barang siap dikonsumsi maka perlu diolah dan dalam proses pengolahan ini diperlukan peralatan baik secara manual maupun menggunakan teknologi permesinan. Oleh karenanya dalam agribisnis terdapat agroindustri yang kegiatan usahanya menggunakan produk-produk hasil pertanian sebagai input dalam usaha agroindustri.

Pengembangan agroindustri merupakan keharusan dalam rangka menuju masyarakat industri yang berbasis pertanian, baik agroindustri berskala besar maupun agroindustri berskala kecil seperti agroindustri rumah tangga. Agribisnis dan agroindustri dua kegiatan 
usaha dibidang pertanian yang mampu menaikkan pendapatan masyarakat baik dipedesaan maupun diperkotaan serta dapat menampung tenaga kerja non skill yang cukup besar. Kegiatan agroindustri ini umumnya melibatkan usaha kecil dan menengah yang merupakan kegiatan ekonomi rakyat yang berskala kecil dengan berbagai kekurangan dan kendala yang dimilki oleh kelompok usaha kecil dan menengah ini.

Pengolahan hasil pertanian seperti padipadian, buah-buahan, ubia-ubian kacang dan sayuran merupakan komponen kedua dalam kegiatan agrobisnis setelah komponen produksi pertanian. Kegiatan pengolahan hasil-hasil pertanian ini sangat penting dalam rangka untuk memenuhi permintaan pasar atau permintaan konsumen terhadap kebutuhan makanan jadi yang siap dikonsumsi baik oleh rumah tangga masyarakat maupun, hotel, restoran, rumah makan dan industri.

Agroindustri yang mengolah komoditi hortikultura khususnya produk buahbuahan sudah mulai berkembang di Provinsi Nusa Tenggara Barat dan produk hasil olahannya merupakan produk lokal yang memiliki ke khasan tersendiri seperti agroindustri olahan pisang sale, kripik pisang, kripik nangka, kerupuk kulit, manisan buah, manisan rumput laut, dodol srikaya, dodol nenas, dodol nangka dan sebagainya. Seperti halnya dodol nangka produk olahan ini memanfaatkan buah nangka sebagai bahan baku utama, dimana buah nangka ini merupakan salah satu tanaman hortikultura yang berbuah setahun sekali dan buah-buahan yang mendapat prioritas untuk dikembangkan sebagai konsumsi buah segar masyarakat berbagai golongan. Dengan adanya pengolahan (agroindustri) buah nangka , maka produsen atau pengusaha industri olahan ini dapat menawarkan bahan pangan sesuai dengan selera konsumen serta memiliki nilai ekonomis yang tinggi dan dayatahan yang cukup lama untuk di konsumsi.

Salah satu Industri kecil pengolahan buah nangka menjdi dodol nangka yang ada di Kecamatan Narmada sebagian besar memiliki kedekatan secara ekonomi dan sosial dengan masyarakat petani karena input bahannya berasal dari hasil-hasil pertanian seperti kedelai untuk kebutuhan agroindustri tahu dan tempe, umbi-umbian untuk usaha keripik singkong, kerupuk kulit dan buah nangka untuk dodol nangka. Kebutuhan akan bahan bangku untuk memenuhi usaha agroindustri cukup besar dan pasokannya harus tetap tersedia dipasaran. Sampai 
sejauhmana produk usaha agroindustri unggulan ini dapat memenurhi permintaan konsumen dengan semakin bertambahnya penduduk diperkotaan , maka perlu dilakukan penelitian tentang “ Analisis Efisiensi usaha Dan Nilai Tambah produk agroindustri olahan Nangka di Kecamatan Narmada Kabupaten Lombok Barat.

\section{Tujuan Penelitian}

1. Menganalisis biaya-biaya yang dikeluarkan dalam satu kali proses produksi usaha pengolahan dodol nangka.

2. Menganalisis tingkat efisiensi usaha agroindustri olahan ini layak untuk dikembangkan atau tidak jika dilihat dari $\mathrm{R} / \mathrm{C}$ ratio nya.

3. Menganalisis besarnya Nilai Tambah yang dihasilkan dari produk olahan dodol nangka di Narmada

\section{Manfaat Penelitian}

1. Sebagai tambahan pengalaman dan pengetahuan yang dapat diterapkan pada mahasiswa dalam proses pembelajaran mata kuliah ekonomi pertanian.

2. Sebagai informasi bagi pihak-pihak yang berkepentingan dalam melakukanm penelitian maupun pengembangan usaha Agroindustri pengolahan makanan khususnya dodol Nangka.

\section{KAJIAN PUSTAKA}

\section{Konsep Industri Pertanian}

Teori Pembangunan pada dasarnya membahas proses pembangunan yang terjadi antara daerah kota dengan daerah pedesaan atau kota dan desa, yang mengikut sertakan proses terjadinya urbanisasi manusia atau perpindahan penduduk desa kearah kota untuk mencari penghidupan dikota. Investasi akan tumbuh dikota sesuai perkembangan kota yang semakin tahun semakin berkembang penduduknya dengan berbagai bidang usaha atau pekerja baik disektor modern maupun disektor tradisional dengan berbagai tingkatan upah yang diterima masyarakat diperkotaan. Tumbuh dan berkembangnya industri kecil diperkotaan mempunyai hubungan yang erat dengan industri pedesaan dan industri pertanian baik dibidang usaha agribisnis maupun usaha dibidang agro industri. Industri pertanian adalah industri yang mengelola hasil dan menghasilkan produk yang digunakan oleh pertanian dan sebagian besar industri kecil adalah industri pertanian. Konsep Industri kecil menurut Deperindak bersama dengan BPS mendefinisikan industri kecil adalah 
kegiatan ekonomi yang dilakukan oleh perseorangan atau rumah tangga maupun suatu badan yang bertujuan untuk memproduksi barang ataupun jasa untuk perniagaan secara komersial, yang memiliki kekayaan bersih paling banyak Rp 200.000.000,- dan mempunyai nilai jumlah lebih besar jika dibandingkan dengan industri besar dan sedang.(Soekartawi 2003).

Seiring dengan perkembangan dan kemajuan zaman serta perkembangan ilmu pengetahuan dan teknologi (IPTEK) maka akan mengakibatkan terjadinya kecenderungan pola transformasi dari pertanian ke industri, yang diketahui bahwa sektor industri merupakan salah satu penyumbang perekonomian di Indonesia. Salah satunya adalah sektor industri pangan yang mengolah hasil pertanian baik nabati maupun hewani menjadi produk olahan. Khususnya industri pangan di Indonesia mempunyai prospek bisnis yang cukup besar kedepan karena keberadaannya selalu dibutuhkan untuk memenuhi kebutuhan masyarakat akan barang makanan, karena

kebutuhan akan pangan merupakan kebutuhan primer bagi manusia yang lebih mendahulukan kebutuhan pangan daripada kebutuhan yang lainnya.
Kegiatan Agribisnis tidak terlepas dengan agroindustri yang kegiatan usahanya menggunakanhasil-hasilpertanian sebagai input atau industri pengolahan hasil pertanian dan perdagangan. Pengembangan agroindustri merupakan suatu keharusan dalam rangka menuju masyarakat industri yang berbasis pertanian.

\section{Pengertian Usaha Tani}

Definisi usaha tani menurut Soekartawi (2003) adalah ilmu yang mempelajari bagaimana mengalokasikan sumberdaya yang dimiliki petani agar berjalan secara efektif dan efisien dan memanfaatkan sumberdaya tersebut agarn memperoleh keuntungan yang setinggi tingginya.

Pengertian usahatani adalah kegiatan untuk meninjau dan menyelidiki berbagai seluk beluk masalah pertanian dan menemukan solusinya. Selanjutnya usahatani adalah pengelolaan sumberdaya alam, tenaga kerja, permodalan dan skill lainnya untuk menghasilkan suatu produk pertanian secara efektif dan efisien (Mubyarto; 1998). Jadi pengertian usahatani secara umum adalah segala bentuk pengorganisasian dan pengelolaan asset serta tatacara yang dilakukan masyarakat petani dalam bidang pertanian dengan tujuan untuk meningkatkan pendapatan 
dan kesejahteraan guna memperbaiki taraf hidup petani.

\section{Pengertian Agroindustri}

Agroindustri berasal dari dua kata agrocultural dan industry yang berarti suatu industri yang menggunakan hasil pertanian sebagai bahan baku utamanya atau suatu industri yang menghasilkan sutu prodarana atau input uk yang digunakan sebagai sarana atau input dalam usaha pertanian. Agroindustri merupakan kegiatan yang memanfaatkan hasil pertanian sebagai bahan baku, merancang dan menyediakan peralatan serta jasa untuk kegiatan tersebut. Proses yang digunakan mencakup pengolahan dan pengawetan melalui perlakuan fisik atau kimiawi, yaitu penyimpanan ,pengemasan dan distribusi. Produk tersebut dapat merupakan produk akhir yang siap dikonsumsi ataupun sebagai produk bahan baku industri lainnya.

Agroindustri adalah industri yang mengolah komoditas pertanian primer menjadi produk produk olahan baik produk antara (intermediate product) maupun produk akhir (finish product), termasuk di dalamnya adalah penanganan pasca panen, industri pengolahan makanan dan minuman, industri biofarmaka, industri bio-energy, industri pengolahan hasil ikutan ( by product) serta industri agrowisata untuk menunjang sektor pariwisata (Dirjen Bina Pengolahan dan Pemasaran Hasil Pertanian, Departemen Pertanian ;2002). Agroindustri penting untuk menjadi lokomotif pertumbuhan ekonomi nasional masa depan, karena (Departemen Pertanian ;2002 ) :

Industri pengolahan mampu mentransformasikan keunggulan komparatif menjadi keunggulan bersaing (kompetitif), yang pada akhirnya akan memperkuat daya saing produk agribisnis Indonesia.

Produknya memiliki nilai tambah dan pangsa pasar yang besar sehingga kemajuan yang dicapai dapat mempengaruhi pertumbuhan perekonomian nasional secara keseluruhan.

Memiliki keterkaitan yang besar baik ke hulu maupun ke hilir ( forward and backward linkages ), sehingga mampu menarik kemajuan sektor-sektor lainnya.

Memiliki basis bahan baku lokal (keunggulan komparatif ) yang dapat diperbaharui sehingga terjamin sustainabilitasnya.

Tujuan yang ingin dicapai dalam pengembangan agroindustri pedesaan adalah untuk meningkatkan kesejahteraan masyarakat pedesaan melalui upaya 
peningkatan nilai tambah dan daya saing hasil pertanian . Untuk mewujudkan tujuan tersebut, pengembangan agroindustri pedesaan diarahkan untuk : Mengembangkan kluster industri, yakni industri pengolahan yang terintregrasi dengan sentar-sentra industri bahan baku serta sarana penunjangnya.

Mengembangkan industri pengolahan skala rumah tangga dan kecil yang didukung oleh industri pengolahan skala menengah dan besar,dan

Mengembangkan industri pengolahan yang punya daya saing tinggi untuk meningkatkan ekspor dan memenuhi kebutuhan dalam negeri.

\section{Analisis Usaha}

Menurut Hermanto (1993) analisis usaha yang dimaksud untuk mengetahui kekuatan pengelola secara menyeluruh sebagai jaminan atau agunan bank serta usahanyan. Informasi ini penting bagi pengelola dalam kedudukannya terkait dengan kredit, pajak-pajak usaha dan pajak kekayaan.

Tiga unsur utama yang berkaitan dengan analisis usaha secara keseluruhan merupakan analisis keuangan tentang arus biaya dan penerimaan ( cash flow), neraca (balance sheet) dan pertelaan pendapatan (income statement).

\section{Analisis Biaya produksi}

Biaya adalah sejumlah nilai uang yang dikeluarkan oleh produsen untuk membiayai kegiatan produksi. Dalam proses produksi, faktor-faktor produksi dikombinasikan, diproses dan kemudian menghasilkan suatu hasil akhir yang biasanya disebut produk (Soekartawi;2003). Biaya produksi dimaksudkan sebagai jumlah kompensasi yang diterima oleh pemilik unsur-unsur produksi yang digunakan dalam proses produksi yang bersangkutan

Ada empat kategori atau pengelompokan biaya (Soekartawi 1998) :

1. Biaya tetap (fixed cost) adalah biaya yang penggunaannya tidak habis dalam satukali masa produksi.

2. Biaya variabel atau berubah-ubah (variabel cost) adalah biaya yang besar kecilnya sangat tergantung kepada biaya skala produksi.

3. Biaya tunai dari biaya tetap dapat berupa air dan pajak tanah, Sedangkan untuk biaya variabel untuk biaya tenaga kerja luar.

4. Biaya tidak tunai (diperhitungkan) meliputi biayatetap dan biaya tenaga keluarga.

Biaya tetap ( fixed cost) didefenisikan sebagai biaya yang relative tetap jumlahnyam dan terus dikeluarkan 
walaupun produksi yang diperolehbanyak atau sedikit. Jadi besarnya biaya tetap ini tidak tergantung padabesar kecilnya produksi yang diperoleh Contohnya pajak. Biaya untuk pajak akan tetap diabayar walaupun hasil usahatani itu besar atau gagal sekalipun. Biaya tetap ini beragam, dan terkadang- kadang tergantung dari peneliti apakah mau memberlakukan variabel itu sebagai biaya tetap ataubiaya variabel( tidak tetap). Contoh biaya tetap antara lain: sewa tanah,pajak, alat pertanian, dan yuran irigasi.Biaya tidak tetap (Variable cost) biasanya didefenisikan sebagai biaya yang besarkecilnya dipengaruhi oleh produksi yang diperoleh. Contohnya biayauntuk sarana produksi. Produksi yang diperoleh. Contohnya biaya untuk sarana produksi kalau menginginkan produksi yang tinggi. Maka tenagakerja perlu ditambah, pupuk juga perlu ditambah dan sebagainya, sehinggabiaya itu sifatnya berubahberubah tergantung dari besar- kecilnya produkiyang diingikan.

Biaya yang digunakan untuk produksi dapat dibedakan menjadi dua macam yaitu :

1. Biaya (eksplisit) adalah biaya yang secara nyata dibayarkan selama proses produksi oleh produsen untuk masukan (input) yang berasal dari luarseperti penggunaan tenaga kerja dan sarana produksi dari luar.

2. Biaya (implicit) adalah biaya dari factor produksi sendiri yangdiikutsertakan dalam proses produksi untuk menghasilkan produk ( output).

Termasuk dalam biaya ini antara lain adalah biaya penyusutan. Sewa tanah milik sendiri. Upah tenaga kerja keluarga dan bunga modal sendiri.

Untuk menghitung total biaya produksi dapat dihitung dengan menggunakan rumus:

$\mathrm{TC}=\mathrm{TVC}+\mathrm{TFC}$ (Soekartawi, 1995)

Keterangan :

$\mathrm{TC}=$ Total Biaya (dalam Rupiah)

TVC $=$ Total Biaya Variabel (dalam Rupiah)

TFC = Total biaya Tetap (dalam Rupiah)

\section{Nilai Tambah}

Nilai tambah suatu produk adalah hasil dari nilai produk akhir dikurangi dengan biaya antara yang terdiri dari biaya bahan baku dan bahan penolong (Tarigan,2011).Nilai tambah merupakan nilai yang ditambahkan kepada barang dan jasa yang dipakai oleh unit produksi dalam proses produksi sebagai biaya antara. Nilai yang ditambahkan ini sama dengan balas jasa atas ikut sertanya faktor produksi dalam proses produksi. Bila komponen biaya antara yang digunakan nilainya semakin besar, maka nilai tambah 
produk tersebut akan semakin kecil. Begitu pula sebaliknya, jika biaya antaranya semakin kecil, makanilai tambah produk akan semakin besar.

\section{METODE PENELITIAN}

\section{Waktu dan Tempat Penelitian}

Penelitian ini dilakukan di Kecamatan Narmada Kabupaten Lombok Barat pada bulan Agustus 2018. Pemilihan lokasi penelitian ditentukan secara sengaja (Purposive) dengan pertimbangan bahwa lokasi tersebut merupakan salah satu tempat usaha industri pengolahan yang menggunakan buah nangka sebagai bahan baku agroinmdustri dodol nangka.

\section{Responden Penelitian}

Penelitian ini mengambil 6 ( enam ) unit usaha sebagai sampel dari sejumlah populasi usaha industri pengolahan dodol nangka yang tersebar di kecamatan Narmada. Penentuan sampel responden dilakukan dengan tanpa sengaja

(Accidental Sampling) yaitu peneliti mengambil sampel yang kebetulan ditemuinya pada saat dilakukan pengumpulan data (Arikunto, Suharsini;2006).

\section{Metode Pengumpulan Data}

Penelitian ini menggunakan data primer dan data sekunder sebagai pendukung analisis. Data primer yang diambil dalam penelitian ini adalah meliputi identitas responden, data produksi, biaya produksi, bahan baku kedelai, tenaga kerja, bahan bakar dan lain-lain. Teknik pengumpulan data dilakaukan dengan observasi, wawancara, dan dokumentasi. Sedangkan data sekunder diperoleh dari instansi yang terkait serta publikasi yang ada kaitannya dengan penelitian.

\section{ANALISIS DATA}

Data-data yang dikumpulkan dalam penelitian ini akan dianalisis secara kualitatif dan kuantitatif . Penggunaan ananalisis kualitatif untuk mendapatkan gambaran kondisi riil usaha agroindustri olahan dilokasi penelitian. Sedangkan data kuantitatif digunakan untuk menganalisis tingkat efisiensi usaha dan perhitungan biaya produksi dan nilai tambah dalam penelitian ini antara lain :

\section{Analisis Penyusutan Peralatan}

Biaya penyusutan peralatan produksi dihitung dengan menggunakan Metode Garis Lurus dengan rumus sebagai berikut $D=P-S / N$

Dimana :

$D=$ Biaya penyusutan peralatan per tahun

$P=$ Harga awal peralatan (Rp)

$S=$ Harga Akhir peralatan (Rp)

$\mathrm{N}=$ Perkiraan Umur ekonomis (tahun)

\section{Analisis Biaya Produksi}

Biaya produksi merupakan penjumlahan biaya tetap dan biaya variabel. Besarnya 
biaya produksi dihitung dengan biaya. Secara matematis dapat persamaan berikut :

dirumuskan sebagai berikut :

$\mathrm{BP}=\mathrm{BT}+\mathrm{BV}$

Dimana :

$\mathrm{R} / \mathrm{C}=$ Total Penerimaan (TR)/ Total Biaya

$\mathrm{BP}=$ Biaya Produksi (Rp/tahun)

Dimana :

BT = Biaya tetap (Rp/tahun)

$\mathrm{BV}=$ Biaya Variabel (Rp/tahun)

Jika $\mathrm{R} / \mathrm{C}>1$, maka Usaha agroindustri

pengolahan dodol nangka

Analisis Penerimaan (Revenue)

menguntungkan untuik diusahakan

Penerimaan Total atau total Revenue dari usaha agroindustri olahan dapat diperoleh dari hasil perankalian antara jumlah produksi tahu yang dihasilkan dikalikan dengan harga tahu, atau secara matematis dapat di tulis :

$T R=P \times Q$

Dimana :

$\mathrm{TR}=$ Total Revenue (total penerimaan $\mathrm{Rp} /$ tahun)

$\mathrm{Q}=$ Kuantitas $(\mathrm{kg})$

$P=$ Harga tahu per kilogram (Rp)

Keuntungan dihitung dengan rumus :

$\pi=\mathrm{TR}-\mathrm{TC}$

Dimana :

$\Pi$ = Keuntungan (Rp/bulan)

$\mathrm{TR}=$ Total Penerimaan kotor (Rp/bulan)

$\mathrm{TC}=$ Total Biaya produksi ( Rp/bulan)an biaya,

\section{Analisis efisiensi Usaha}

Perhitungan efisiensi usaha agroindustri yang digunakan adalah Revenue Cost Ratio (R/C Ratio) R/C Ratio adalah perbandingan antara penerimaan dengan Jika $\mathrm{R} / \mathrm{C}<1$, maka usaha agroindustri pengolahan dodol nangka tidak layak untuk diusahakan (merugi).

Analisis Nilai Tambah dengan rumus sebagai berikut :

$\mathrm{NTp}=\mathrm{Na}-\mathrm{Ba}$ $\mathrm{Ba}=(\mathrm{Bb}+$

$B p+B b p)$

Keterangan :

NTp = Nilai Tambah Produk (Rp)

$\mathrm{Na}=$ Nilai Produk Akhir $(\mathrm{Rp})$

$\mathrm{Ba}=$ Biaya antara

$\mathrm{Bb}$ = Biaya bahan baku (Rp)

$\mathrm{Bp}=$ Biaya penyusutan alat $(\mathrm{Rp})$

$\mathrm{Bbp}=$ Biaya bahan penolong $(\mathrm{Rp}$

\section{HASIL DAN PEMBAHASAN}

\section{Gambaran Umum Usaha Agroindustri} Dodol Nangka

Kecamatan Narmada di Kabupaten Lombok Barat merupakan salah satu kawasan yang terkenal sebagai penghasil makanan dodol nangka selain juga terkenal dengan usaha olaha daging sapi sate bulayak yang menjadi makanan khas 
daerah Narmada. Hal ini dapat dilihat dari banyaknya pengusaha dodol nanghka khususnya yang dapat ditemukan di wilayah Narmada. Usaha Agroindustri pengolahan dodol nangka memang sangat potensial untuk dikembangkan mengingat dodol merupakan salah satu makanan yang banyak disukai oleh masyarakat di Lombok maupuin masyarakat luar daerah karena dodol nangka memiliki citarasa yang khas serta harganya terjangkau.

Satu produk unggulan yang patut dikembangkan selain banyak dikonsumsi oleh mayarakat lokal juga dodol nangka ini menjadi oleh oleh produk makanan khas Lombok yang diminati oleh para wisatawan dalam negeri maupun wisatawan luar negeri. Oleh karenanya perlu dilakukan suatu kajian yang mendalam terkait kedepan bagaimana usaha agroindustri pengolahan dodol nangka ini dapat dikembangkan sesuai dengan keinginan poasar yaitu kualitas produk, citarasa produk, kemasan produk dan daya jangkau pemasaran produk sehingga pengusaha dodol nangka ini kedepannya dapat lebih berkembang usahanya serta dapat meningkatkan pendapatan rumah tangga mereka.;

Dodol nangka ini merupakan penganan tradisional khas Indonesia artinya disetiap daerah terdapat banyak produksi dodol nangka yang diusahakan oleh industri rumah tangga. Sesuai namanya dodol nangka memang dibuat menggunakan dari bahan dasar buah nangka yang segar dan sudah matang yang kemudian diolah dengan berbagai macam bahan tambahan yang lain seperti gula pasir yang emaupun gula merah dari kelapa atau gula aren, santan, vanili dan tepung bila diperlukan, sehingga membuat dodol nangka memiliki rasa begitu enak, nikmat dan kenyal namun sangat lembut dilidah pada saat mengkonsumsi.

\section{Cara Membuat Dodol Nangka}

Siapkan bahan-bahan yang diperlukan seperti buah nangka bahan pokok yang utama, kemudian bahan penolong gula pasir atau gula batu atau gula aren, vanili secukupnya dan lain lain. Setelah bahanbahan tersebut disiapkan barulah tahap awal yang dilakukan dalam pembuatan dodol nangka adalah :

Tahap awal ambil satu persatu buah nangka yang sudah disiapkan, lalu di iris iris kecil .

Siapkan satu buah wajan ukuran sedang lalu masukkan semua irisan buah nangka kedalam wajan.

Tuangkan minyak sayur atau santan kelapa kedalam wajan yang berisi nangka sambil dimasak di atas api 
kompor.selanjutnyan hingga mengental dan terasa kenyal.

Tunggu hingga dodol nangka dingin lalu potong-potong sesuai ukuran dan selera yang diinginkan.

Selanjutnya dodol nangka di jemur agar diperoleh kepadatan yang baik dan tahan lama untukdisajikan.

Bungkus dengan kertas wajik atau pelastik atau kelopak jagung kering hingga terbentuk.

Masukkan dalam kemasan plastik mika atau kotak untuk dipasarkan.

\section{Analisa Usaha Dodol Nangka}

1. Analisis Biaya Penyusutan

Peralatan yang digunakan dalam proses produksi dodol nangka ini terdiri dari wajan penggoreng, pengaduk, kompor gas, tabung gas, wadah, baskom,timbangan

dan serbet. Peralatan ini diperoleh dengan membeli yang harganya berpariasi serta jumlah unitnya juga tidak sama antara satu industri dengan industri nangka lainnya. Peralatan ini digunakan selama dalam proses produksi sudah barang tentu akan menyusut nilainya, oleh karenanya dalam sekali proses produksi nilai peralatan ini dihitung penyusutannya yang akan diperhitungkan sebagai biaya tetap (fixed Cost). Berikut biaya peralatan dan nilai penyusutan peralatan sekali proses produksi :

Tabel 1. Nilai peralatan usaha agroindustri dodol

\begin{tabular}{|l|l|c|c|c|}
\hline No & Jenis Peralatan & $\begin{array}{c}\text { Jumlah } \\
\text { (unit) }\end{array}$ & $\begin{array}{c}\text { Harga Pembelian } \\
\text { (Rp) }\end{array}$ & $\begin{array}{c}\text { Nilai Sisa } \\
\text { (Rp) }\end{array}$ \\
\hline 1. & Wajan Penggorengan & 1 & 175.000 & 10.000 \\
\hline 2. & Kompor & 1 & 300.000 & 30.000 \\
\hline 3. & Tabung Gas & 1 & 150.000 & - \\
\hline 4. & Pisau & 1 & 20.000 & - \\
\hline 5. & Pengaduk & 1 & 75.000 & 5.000 \\
\hline 6. & Baskom & 1 & 30.000 & - \\
\hline 7. & Nampan & 1 & 25.000 & - \\
\hline 8. & Serbet/Lap kain & 1 & 5.000 & - \\
\hline 9. & Wadah & 1 & 15.000 & \\
\hline
\end{tabular}

Pada tabel 1. Di atas memperlihatkan sarana produksi dan nilai peralatan yang digunakan dalam proses pembuatan dodol nangka dimana harga yang tercantum merupakan harga pasar yang berlaku pada saat penelitian yang diperoleh dari responden. Selanjutnya dari nilai pembelian peralatan tersebut akan dihitung nilai penyusutan peralatan dilihat dari umur ekonomisnya. 
Tabel 2. Biaya Penyusutan Peralatan Usaha Agroindustri Dodol Nangka

\begin{tabular}{|l|l|c|l|c|c|}
\hline No & Jenis Alat & $\begin{array}{l}\text { Jumlah } \\
\text { (unit) }\end{array}$ & $\begin{array}{l}\text { Harga } \\
\text { Pembelian }\end{array}$ & $\begin{array}{l}\text { Umur } \\
\text { Ekonomis }\end{array}$ & $\begin{array}{l}\text { Nilai Penyut /proses } \\
\text { produksi }\end{array}$ \\
\hline 1 & Wajan & 1 & 175.000 & 3 & $4.583,33$ \\
\hline 2 & Kompor & 1 & 300.000 & 5 & $4.500,00$ \\
\hline 3 & Tabung gas & 1 & 150.000 & 5 & $1.250,00$ \\
\hline 4 & Wadah & 1 & 15.000 & 1 & $1.250,00$ \\
\hline 5 & Pengaduk & 1 & 75.000 & 2 & $2.916,66$ \\
\hline 6 & Baskom & 1 & 30.000 & 3 & 833,33 \\
\hline 7 & Nampan & 1 & 25.000 & 2 & $1.041,66$ \\
\hline 8 & Serbet/Lap & 1 & 5.000 & 1 & 416,67 \\
\hline 9 & Pisau & 1 & 20.000 & 2 & 833,33 \\
\hline & & & & & $17.624,98$ \\
\hline
\end{tabular}

Tabel 2. Di atas menunjukkan biaya penyusutan per alat yang digunakan dalam proses produksi yang dihitung dalam satu kali proses produksi. Dalam perhitungan penyusutan peralatan ini diperoleh nilai penyusutan dari peralatan yang digunakan yaitu sebesar $\mathrm{Rp}$ $17.624,98$ dengan jumlah proses produksi yang berbeda setiap pengusaha. Berikut rata-rata biaya penyusutan per responden usaha dodol nangka selama satu bulan :

Tabel 3. Rata-Rata Biaya penyusutan Penggunaan Peralatan Usaha Agroindustri dodol Nangka Per Responden Sebulan

\begin{tabular}{|l|l|c|c|}
\hline No & Nama Responden & Proses Produksi & Penyusutan Alat (Rp) \\
\hline 1. & Inaq Sari & 10 & 19.708 \\
\hline 2. & Imron & 10 & $18.874,98$ \\
\hline 3. & Widya & 12 & $24.291,64$ \\
\hline 4 & Asdi & 10 & $25.541,64$ \\
\hline 5. & Mahdi & 10 & $23.874,97$ \\
\hline 6 & Rani & 12 & $22.041,64$ \\
\hline
\end{tabular}

Sumber : Data lampiran diolah

Tabel 3. di atas memperlihatkan total biaya penyusutan yang dikeluarkan oleh usaha agroindustri pengolahan dodol nangka per alat yang digunakan yaitu masing-masing responden berpariasi jumlahnya karena jumlah yang dimiliki berbeda oleh setiap pengusaha dodol dalam proses produksinya. 
Tabel 4. Biaya-Biaya yang dikeluarkan Agroindustri Pengolahan Dodol Nangka

\begin{tabular}{|c|c|c|c|c|c|c|}
\hline \multirow{2}{*}{$\begin{array}{l}\text { Nama } \\
\text { Responden }\end{array}$} & \multirow{2}{*}{$\begin{array}{l}\text { Tenaga } \\
\text { Kerja } \\
\text { (Org) }\end{array}$} & \multicolumn{2}{|c|}{ Biaya Lainnya } & \multirow{2}{*}{$\begin{array}{l}\text { Biaya } \\
\text { Bahan } \\
\text { Baku (Rp) }\end{array}$} & \multirow{2}{*}{$\begin{array}{l}\text { Biaya Tetap } \\
\text { (Rp) }\end{array}$} & \multirow{2}{*}{$\begin{array}{l}\text { Total Biaya } \\
\text { (Rp) }\end{array}$} \\
\hline & & TK (Rp) & $\begin{array}{l}\text { Bahan } \\
\text { Penolong }\end{array}$ & & & \\
\hline Inaq Sari & 2 & 80.000 & 60.000 & 50.000 & $19.708,50$ & $209.708,50$ \\
\hline Imron & 2 & 80.000 & 65.000 & 60.000 & $18.874,98$ & $223.874,98$ \\
\hline Widya & 3 & 120.000 & $150 . .000$ & 100.000 & $24.291,64$ & $394.291,64$ \\
\hline Asdi & 4 & 160.000 & $175 . .000$ & 130.000 & $25.541,64$ & $490.541,64$ \\
\hline Mahdi & 2 & 80.000 & 80.000 & 60.000 & $23.874,97$ & $243.874,97$ \\
\hline Rani & 2 & 80.000 & 96.000 & 70.000 & $22.041,64$ & $268.041,64$ \\
\hline
\end{tabular}

Data pada tabel 4, memperlihatkan komponen biaya-biaya yang dikeluarkan dalam proses pengolahan produksi dodol nangka dari 6 (enam) responden pengusaha dodol nangka. Biaya Tenaga kerja untuk 1 orang tenaga kerja diupah sebesar Rp 40.000, dengan penggunaan tenaga kerja 2 sampai 4 orang tenaga kerja. Biaya-biaya lainnya terdiri dari Bahan Penolong yaitu minyak goreng, gula pasir/gula aren, dan vanila bubuk yang kisaran biayanya antara Rp 30.000 sampai dengan Rp 80.000,- Biaya variabel dimana biaya yang dikeluarkan besar kecilnya mempengaruhi produksi dalam hal ini pembelian bahan baku utama nangka yang per kilo harganya Rp 1.500,- jadi satu bungkul nangka ditimbang kalikan dengan Rp 1.500,- Biaya tetap berupa biaya dalam proses produksi yang berkisar antara Rp 18.874,98 sampai dengan $\mathrm{Rp}$

25.541,64. , dan selanjut biaya total merupakan penjumlahan dari seluruh biaya yaitu kisaran antara $\mathrm{Rp} 178.874,98$ sampai dengan tertinggi Rp 314.291,64 .

\section{Penerimaan Usaha Dodol Nangka}

Penerimaan usaha Agroindustri pengolahan dodol nangka diperoleh sdarin perkalian dari output dodol nangka yang dihasilkan denghan harga per unit selama sekali proses produksi . Dari ke enam responden jumlah penerimaan yang diperoleh berpariasi dimana besar kecilnya penerimaan tergantung dari besar bahan baku dan biaya yang dikeluarkan. 
Tabel 5. Penerimaan Usaha Agroindustri Pengolahan Dodol Nangka sekali proses produksi

\begin{tabular}{|l|l|c|c|c|l|c|}
\hline No & $\begin{array}{l}\text { Nama } \\
\text { Responden }\end{array}$ & $\begin{array}{l}\text { Produksi } \\
\text { (Unit) }\end{array}$ & $\begin{array}{l}\text { Harga } \\
\text { Satuan } \\
(\mathrm{Rp})\end{array}$ & $\begin{array}{l}\text { Total } \\
\text { Revenue } \\
(\mathrm{Rp})\end{array}$ & $\begin{array}{l}\text { Total Cost } \\
(\mathrm{Rp})\end{array}$ & $\begin{array}{l}\text { Pendapatan } \\
\text { Bersih (Rp) }\end{array}$ \\
\hline 1. & Inaq Sari & 55 & 10.000 & 550.000 & $209.708,50$ & $340.291,50$ \\
\hline 2. & Imron & 50 & 10.000 & 600.000 & $223.874,98$ & $376.125,02$ \\
\hline 3 & Widya & 120 & 10.000 & 1.200 .000 & $394.291,64$ & $805.708,36$ \\
\hline 4 & Asdi & 130 & 10.000 & 1.300 .000 & 490.541 .64 & $809.458,36$ \\
\hline 5 & Mahdi & 60 & 10.000 & 600.000 & $243.874,97$ & $356.125,03$ \\
\hline 6 & Rani & 85 & 10.000 & 850.000 & $268.041,64$ & $581.958,36$ \\
\hline
\end{tabular}

Data pada tabel 5 di atas memberi informasi bahwa capaian produksi dodol nangka antara 50 unit sampai dengan 120 unitdengan harga rata-rata per unit $\mathrm{Rp}$ 10.000 ,-dan penerimaan kotor (TR) antara Rp 550.000 sampai dengan $\mathrm{Rp}$ 1.300.000,- $\quad$ Sedangkan pendapatan bersih yang diterima usaha agroindustri dodol nangka per responden yaitu kisaran antara $\mathrm{Rp} 370.291,50$ terendah dan tertinggi Rp 904.458,36,- Besar kecilnya pendapatan yang diterima pengusaha dodol nangka di Kecamatan Narmada sangat ditentukan oleh volume produksi Tabel 6. Tingkat Efisiensi Usaha Dodol Nangka di Kecamatan Narmada

\begin{tabular}{|l|l|c|c|c|}
\hline No & Nama Responden & Total Revenue & Total Cost & Efisiensi (R/C) \\
\hline 1. & Inaq Sri & 550.000 & $209.708,50$ & 2,62 \\
\hline 2. & Imron & 600.000 & $223.874,98$ & 2,68 \\
\hline 3. & Widya & 1.200 .000 & $394.291,64$ & 3,04 \\
\hline 4 & Asdi & 1.300 .000 & $490.541,64$ & 2,65 \\
\hline 5 & Maldi & 600.000 & $243.874,64$ & 2,46 \\
\hline 6. & Rani & 850.000 & $268.041,64$ & 3,17 \\
\hline
\end{tabular}

Tingkat efisiensi usaha pengolahan dodol nangka cukup tinggi artinya dari data-data pada tabel 6 di atas hasil analisis dan pengeluaran biaya produksi dalam sekali proses produksi.

\section{Analisis efisiensi Usaha}

Perhitungan efisiensi usaha agroindustri yang digunakan adalah Revenue Cost Ratio (R/C Ratio) R/C Ratio adalah perbandingan antara penerimaan dengan biaya.Secara matematis dapat dirumuskan sebagai berikut:

$\mathrm{R} / \mathrm{C}=$ Total Penerimaan (TR)/ Total Biaya (TC)

menunjukkan bahwa angka efisiensi ratarata di atas 1 atau jika Revenue Cost Ratio (R/C Ratio) nilainya > 1, maka Usaha 
agroindustri pengolahan dodol nangka menguntungkan untuik diusahakan

\section{Analisis Nilai Tambah Agroindustri}

\section{Pengolahan Dodol Nangka}

Nilai tambah dalam produksi dodol nangka dapat didefinisikan yaitu total pendapatan yang diterima dari penjualan ouput tersebut (dodol nangka), dan biaya masukan dari bahan-bahan mentah yang dibeli untuk memproduksi dodol nangka.
Nilai tambah usaha pengolahan dodol nangka dilakukan untuk mengetahui besarnya nilai yang ditambahkan pada bahan baku yang digunakan yaitu buah nangka.. Berikut ini perhitungsn nilai tambah pengolahan dodol nangka adalah sebagai berikut :

$\mathrm{NTp}=\mathrm{Na}-\mathrm{Ba}$ $\mathrm{Ba}=(\mathrm{Bb}+$

$B p+B b p)$

Tabel 7. Nialai Tambah Pengolahan Dosdol Nangka Sekali Proses Produksi

\begin{tabular}{|l|l|l|l|l|}
\hline No & $\begin{array}{l}\text { Nama } \\
\text { Responden }\end{array}$ & Perhit Nilai Tambah (NTp) & NTp Usaha & $\begin{array}{l}\text { NTp Bahan } \\
\text { Baku }\end{array}$ \\
\hline 1. & Inaq Sri & $=550.000-(50.000+60.000+19.708)$ & 420.292 & $\begin{array}{l}420.292 / 5= \\
84.058,4\end{array}$ \\
\hline 2. & Imron & $=600.000-(60.000+65.000+18.874,98)$ & $456.125,2$ & $\begin{array}{l}456.125,2 / 6 \\
=76.020,84\end{array}$ \\
\hline 3 & Widya & $=1.200 .000-(100.000+150.000+$ \\
$24.291,64)$ & 925.708 & $\begin{array}{l}925.708,36 \\
/ 10 \\
92.570,84\end{array}$ \\
\hline 4 & Asdi & $=1.300 .000-(130.000+175.000+$ & $969.125,03$ & $\begin{array}{l}969.125,03 \\
/ 13= \\
74.548,08\end{array}$ \\
\hline 5 & Maldi & $=600.000-(60.000+80.000+19.874,97)$ & $440.125,03$ & $\begin{array}{l}440.125,03 \\
/ 6= \\
73.354,17\end{array}$ \\
\hline 6 & Rani & $=850.000-(70.000+96.000+22.041,64)$ & $661.958,03$ & $\begin{array}{l}661.958,03 \\
/ 7= \\
94.565,43\end{array}$ \\
\hline
\end{tabular}

Berdasarkan perhitungan pada tabel 7 tersebut di atas besarnya nilai tambah yang didapat dari usaha agroindustri pengolahan dodol nangka Inaq Sari adalah Rp 420.292 , sedangkan besarnya nilai yang ditambahkan untuk bahan baku dodol nangka per $1 \mathrm{Kg}$ nangka sebesar Rp $84.058,40,-$, artinya bahwa untuk setiap
$1 \mathrm{Kg}$ buah nangka yang diolah menjadi dodol nangka dapat memberikan penambahan nilai sebesar $84.058,40$. Hasil analisis pada ke enam responden menunjukkan bahwa Rata-rata Nilai Tambnah agroindustri olahan dodol nangka sebesar 82.519,56, ini menunjukkan produk olahan dodol 
nangka memiliki prospek yang baik jika dilihat dari nilai tambah yang dihasilkan dan juga produk makanan dodol ini banyak digemari oleh konsumen baik untuk dikonsumsi sendiri maupun untuk oleh-oleh.

\section{KESIMPULAN DAN SARAN}

\section{Kesimpulan}

Hasil analisis menunjukkan bahwa besarnya biaya rata-rata sekali produksi pengolahan dodol nangka dari ke enam responden adalah berkisar antara $\mathrm{Rp}$ 209.874, yang terendah dan tertinggi sebesar $\mathrm{Rp}$ 490.541,64 dengan rata-rata perolehan pendapatan mencapai antara Rp 357.513,67 sampai dengan Rp 807.583 dalam sekali proses produksi. Sedangkan nilai tambah yang diciptakan dari pengolahan buah nangka menjadi dodol nangka pada ke enam responden menunjukkan bahwa Rata-rata Nilai Tambah agroindustri olahan dodol nangka sebesar Rp 82.519,56, artinya bahwa untuk setiap $1 \mathrm{Kg}$ buah nangka yang diolah menjadi dodol nangka dapat memberikan penambahan nilai sebesar $82.519,56$. ini menunjukkan produk olahan dodol nangka memiliki prospek yang baik jika dilihat dari nilai tambah yang dihasilkan.

\section{Saran}

Hendaknya pengusaha industri dodol nangka di kecamatan Narmada lebih meningkatkan mutu dan cita rasa produk dengan mengemas dodol nangka menggunakan kemasan kotak ber merk logo usaha agar dapat dipasarkan ke toko oleh oleh atau ke supermart agar usahanya lebih berkembang.

\section{DAFTAR PUSTAKA}

Anonim Dirjen Bina Pengolahan dan Pemasaran Hasil Pertanian, Departemen Pertanian ;2002).

Arikunto.Suharsini.2006. Prosedur Penelitian. Suatu pen.dekatan Praktik. PT. Reneka Cipta. Jakarta

Aryo Demarto,dkk.2003. Sektor informal alternatip kesempatan kerja Bagi Golongan Berpendidikan Rendah. Makalah Diklat Universitas Sebelas Maret.

Kartasasmita M. 2011. Pengertian Agroindustri . Blogspot.com. 2011

Mubyarto.1998. Konsep Biaya Industri Kecil. Gramedia Jakarta 
Nasir, Mohammad. 2009. Metode Penelitian. Graha Indonesia. Jakarta.

Putong Iskandar. 2002. Pengantar Ekonomi Mikro dan Makro. Galia Indonesia Santri Y,M. 2009. Analisis Usaha Agroindustri Keripik Belut di Kabupaten Klaten. Program Studi Agribisnis Fakultas Pertanian Universitas Sebelas Maret Surakarta.

Sudiyono. 2004. Pemasaran Pertanian .UMM.Malang

Sukartawi. 2003. Agribisnis. Teori dan Aplikasinya. PT. Raja Grafindo Persada Jakarta. 